\title{
THE ECONOMIC EFFICIENCY OF OUTSOURCING OF TRANSPORT AND LOGISTICS SERVICES. CASE STUDY OF THE POLISH ROAD TRANSPORT MARKET
}

\section{DARIUSZ MILEWSKI}

University of Szczecin, POLAND

e-mail: dariusz.milewski@wzieu.pl

RECEIVED
ACCEPTED
JEL
CLASSIFICATION
KEYWORDS

ABSTRACT
12 May 2018

7 September 2018

L20, L91, M20

outsourcing of transport and logistics services, economical effectiveness of transportation process, modeling, simulation

The paper deals with the problem of the economic efficiency of outsourcing of organization of transport processes. It presents the results of the research studies from the literature and also research made with the use of an electronic model of economic benefits of cooperation with an external service provider. The model was developed by the Author of the paper and was used to make simulations of different strategies from the perspective both of a carrier and a transport user. According to the results profitability depends rather on the parameters of a process of delivery of goods - average demand, standard deviation, weight and value of transported commodities than on the costs of transport.

\section{Introduction}

The strategy of outsourcing is widespread in the economy. The reasons may be lower costs or higher quality of goods or services of an external provider, which can be more efficient due to e.g. the scale of operations, high efficiency of processes, high competence, experience. In the field of transport and logistics the outsourcing can be applied on different stages of a process of a delivery of goods - transport, warehousing, transshipment or 
organization of these processes, which can be dealt by a forwarder or a logistics service provider. So the question here arises - what is the justification for the use of such an intermediary of between a shipper (transport user) and a transportation carrier.

The goal of the research made the Author of the paper was to investigate in which circumstances both a carrier and a transport user can achieve the benefits of cooperation with an organizer of a transportation process and how big these benefits can be.

\section{Litepgture review}

A customer achieves numerous benefits in cooperation with a freight forwarder (Załoga, Milewski, 2004): professional counseling in the process of concluding a commercial contract, preparation, completion of documents necessary for the proper implementation of the shipment process, increase of the efficiency of the transportation process, obtaining lower prices for transportation services, lower administration costs, guarantee of payment by a client and reliable performance of a service by a carrier. A freight forwarder knows the transport market, has a network of contacts and is able to offer a higher level of services. A forwarding company also can play a financial role - for example, the customs protection, which allows timely completion of customs formalities and reduce administrative time spent in the cargo customs clearance points. It cover freight charges in order to avoid delays in deliveries. A professional freight forwarders can help in solving unusual problems by proposing innovative solutions for trans-loading or securing goods during transport.

Cooperation with a forwarder is also beneficial for carriers (Załoga, Milewski, 2004). A transportation company doesn't have to deal with the acquisition of transport orders from many transport users and finally with collection of payment from many small customers. A freight forwarders deals with the organization of transportation process on all stages, can better prepare goods for shipment, invest in infrastructure, equipment, acquires new customers, can develop new form of services.

The preferences of transport users vary depending on different factors. For competitiveness of maritime transport a price may be even more important than in the road transport (Bergantino, Bierlaire, Catalano, Migliore, Amoroso, 2013). According to other studies the performance of port operations are of primary importance (Tongzon, 2009).

According to various studies the quality requirements outweighed cost (Danielis, Marcucci, Rotaris, 2005). This is in contrast with observations of behavior of entrepreneurs made for example by the Author of this paper. Very often for transport users price is the only criterion for choosing a carrier or a freight forwarder.

It may seem, that a choice between hired and in-house transport depends to some extent on the characteristic of a cargo transported. In case of specialized technology the propensity to outsource transport services is often lower (Wysocka, 2013).

According to Mirosław Kaczmarek of Polish Chamber of Freight Forwarding and Logistics (2013) very few companies deserve to be called freight forwarding the full sense of this expression. Freight forwarding activity is mostly carried out by road freight forwarding companies. According to the author's of the report rail freight forwarding practically doesn't exist in Poland, because it is characterized by a higher than road haulage degree of complexity and required competence.

The phenomenon for outsourcing of transport and logistics services in the food industry in Taiwan and Netherlands has been studied by H.I. Hsiao, R.G.M. Kemp, J. van der Vorst, S.W.F. Omta, (2011). In the Netherlands 
outsourcing in transport and packaging are used more frequently, what may be probably due to the fact that the Thai companies emphasis on cost reduction and the Dutch ones on flexibility. The dairy industry also uses external services to a greater extent than the meat industry, which can be explained by the fact that the latter emphasis on the quality of the food while the dairy industry on flexibility and reliability of supplies.

In recent years views have been expressed that freight forwarding services are to replaced entirely by logistics services. Also the development of information technologies - e.g. the electronic freight exchanges is sometimes perceived as a threat to freight forwarders, because carriers and transport users can contact directly with each other through an electronic platform. Such views are being presented since 90s (Ozsomer, Mitri, Cavusgil, 1993; Here, Murphy, Daley, 1995), but it seems, that these predictions have not come true. Freight forwarders still exist on the market, although indeed the market of alternative services to the freight forwarding is growing rapidly. However, regardless of the phenomena occurring on the market, the problem of the economic efficiency of organization of a delivery of goods still exists. Using a freight exchange is also costly. A "Third party" logistics operator also acts as an intermediary, because often such companies don't utilize their own fleet but hire external carriers. So still, the question arise what are the benefits of using such services both for a carrier and a transport user?

\section{Model of economical efficiency of cooperation with an organizer of a delivery of goods}

In order to study economical efficiency of the cooperation of a road carrier and a transport user with an organizer of transport a simulation model has been developed. The simulation concerns the Polish market of the road transport and freight forwarding services. Data have been obtained from companies offering such services and the construction of the model has been consulted with practitioners.

The simulations have been made for different variants -3 three options of a cooperation:

- "Direct",

- "Better productivity",

- "Better service".

"Direct" means, that a transport user uses transport services without an intermediary of freight forwarder and although the prices for the transport services are relatively high, the efficiency of a transport process is low - lower level of mileage $(110,000 \mathrm{~km} /$ year) and more empty runs (only $80 \%$ of mileage stands for the loaded transport);

"Better productivity" is obtained thanks to the more effective cooperation with an organizer of transport - more orders for a transport carrier (130,000 km/year) and more loaded runs (85\%). However, because the organizer has to attract a transport user to cooperate, it offers a lower price.

Quite different strategy can be applied, when a freight forwarder offers a "Better service", for which prices are also higher than in the strategy "Better productivity". Better service means here a couple of benefits for a transport user: shorter lead time and better punctuality and lower level of damages of transported goods (very serious problem in road transport). The utilization of transport vehicles is however lower $(115,000 \mathrm{~km} /$ year and fewer loaded runs $80 \%$ ), because the transport potential has to be dedicated to the requirements of logistics processes of a transport user. Next assumption relates to the costs of a transport carrier, which are also relatively higher in this option - e.g. better and more expensive transport equipment and higher salaries of drivers.

These three variants are modified by changing: demand fluctuations, weight of goods transported and value of them. In total 12 variants have been used. One can expect that the benefits of cooperating with a freight forwarder for a transport user will be higher in case of more expensive goods and relatively more unstable demand. In such 
cases logistics costs are higher (in this case - costs of capital tied up in inventories and costs of lost sales). On the other hand however in case of higher values of goods the share of logistics costs in total costs is lower, what should diminish their impact on the overall profitability.

The model, contrary to other models presented in the scientific literature is not of aggregated character but is detailed one and thus can reflect real processes. That means that mathematical formulas have not been applied for calculating for example inventory costs but processes are being simulated on a daily basis. Building such a model and its use is relatively more complicated but the Author believes that such method guarantees more precise results.

Table 1. Input data for calculation of economic effectiveness of a road carrier (domestic transport)

\begin{tabular}{lcc}
\hline \multicolumn{1}{c}{ Variant } & Variant "Better productivity" & Variant "Better productivity" \\
\hline Load capacity (tonnes) & 25 & 25 \\
Purchase value of vehicle (PLN) & 420,000 & 450,000 \\
Price of petrol (PLN/l) & 3.49 & 3.49 \\
Petrol consumption (I/100 km) & 33 & 33 \\
Road fee - ViaToll (PLN/km) & 0.37 & 0.37 \\
Number of roads covered by ViaToll & $50 \%$ & $50 \%$ \\
Tire wear (PLN/km) & 0.04 & 0.04 \\
Mileage (km/year) & 110,000 & 130,000 \\
Use of mileage & $80 \%$ & $85 \%$ \\
Average speed $(\mathrm{km} / \mathrm{h})$ & 55 & 55 \\
\hline
\end{tabular}

Source: own on the base of data collected from the Polish transportation market in 2017 year.

First the economical efficiency of a road transport carrier has been calculated. The input data and assumptions are shown in table $1-4$. With the use of these data the simulations have been performed in order find out what is the impact of freight rates of a carrier on economical efficiency of both sides.

Table 2. Fixed costs per 1 vehicle (PLN/year)

\begin{tabular}{lcc}
\hline \multicolumn{1}{c}{ Variant } & Variant “Better productivity” & Variant "Better productivity" \\
\hline Depreciation & 84,000 & 90,000 \\
Insurance & 13,658 & 13,658 \\
Tax on means of transport & 1,534 & 1,534 \\
Wages of drivers & 120,000 & 132,000 \\
Fixed costs of a vehicle & 135,192 & 147,192 \\
Management costs & 4,500 & 4,500 \\
\hline Total fixed costs & 358,884 & 388,884 \\
\hline
\end{tabular}

Source: own on the base of data collected from the Polish transportation market in 2017 year.

Tahle 3. Parameters of transported commodities

\begin{tabular}{lll}
\hline Commodity & Buildings materials & Garments \\
\hline
\end{tabular}




\begin{tabular}{lcc}
\hline Maximal possible demand (tonnes/year) & 1,500 & 820 \\
Density of a commodity (tonnes $/ \mathrm{m}^{3}$ ) & 0.28 & 0.15 \\
Tonnage in a vehicle (tonnes) & 25 & 14 \\
Purchase value of a commodity (PLN/tonne) & 520 & 14,035 \\
\hline
\end{tabular}

Source: own on the base of data collected from the Polish transportation market in 2017 year.

Table 4. Assumptions for the cost calculation of transport users

\begin{tabular}{lcc}
\hline \multicolumn{1}{c}{ Variant } & Variant "Better productivity" & Variant "Better productivity" \\
\hline Annual rate of capital tied up in inventories (\%) & 30 & 30 \\
Warehousing costs (PLN/day/pellet) & 8 & 8 \\
Level of logistics customer service (\%) & 96.2 & 99.7 \\
Level of damages (\%) & 5.0 & 0.5 \\
\hline
\end{tabular}

Source: own on the base of data collected from the Polish transportation market in 2017 year.

\section{Results}

The results are shown on figures 1 and 2. The starting point is the variant of the direct cooperation between a carrier and a transport user. The assumed freight rate in this variant is $3.5 \mathrm{PLN} / \mathrm{km}$.

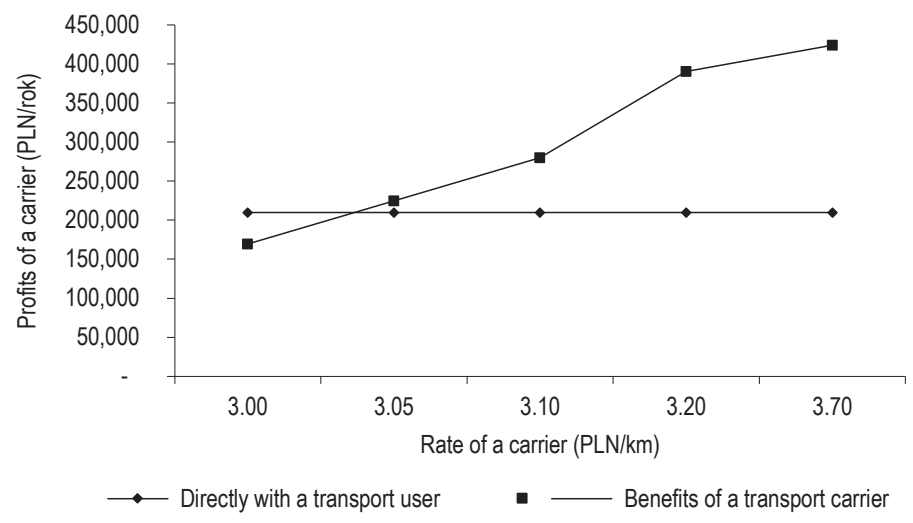

Figure. 1 Benefits of cooperation with an organizer of transport for a carrier

Source: own on the base of data collected from the Polish transportation market in 2017 year

The level of freight rates has the significant impact on the profitability of a road carrier. Despite higher productivity of a carrier in case of cooperation with an organizer of transport, a freight rate cannot be too low - the minimum acceptable price for the transportation service is 3,1 PLN/km (3.26 PLN/km for an organizer of transport 
and a transport user). Such price on the other hand is the highest acceptable price for a transport user and this level will be used in the next calculations.

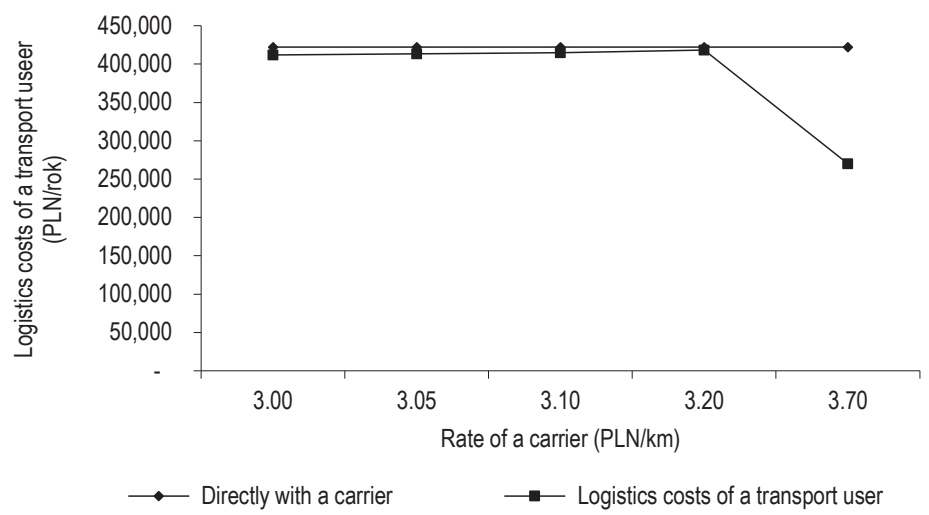

Figure. 2 Benefits of cooperation with an organizer of transport for an transport user

Source: own on the base of data collected from the Polish transportation market in 2017 year.

The rate for a better service, when the productivity is lower in comparison to the variant "Better productivity", is much higher - 3.7 PLN/km for the carrier and 3.89 PLN/km for a transport user. Despite this considerable increase of the price a transport user obtains the reduction of overall logistics costs thanks to the good logistics customer service. It is worth notice, that changes of freight rates without changing the service level don't have big impact on profitability of a transport user (see Figure 2). These results of simulation can raise a question what is the justification for the common practice of transport users for economizing on transport costs? Do they properly calculate all costs and benefits of cooperating with a good service provider?

Next calculations for the rest of variants have been made with the use of the above results: $3.5 \mathrm{PLN} / \mathrm{km}$ for the direct cooperation, $3.10 \mathrm{PLN} / \mathrm{km}$ for the cooperation with an transport organizer and 3.7 PLN/km for better service. The results of simulations are shown in Table 5 .

Tahle 5. Synthesis of simulation results for all variants

\begin{tabular}{lcccc}
\hline \multirow{2}{*}{ Variant } & \multicolumn{2}{c}{ Small variety of sales } & \multicolumn{2}{c}{ Bigger variety of sales } \\
\cline { 2 - 5 } & better productivity & better service & better productivity & better service \\
\hline Rate of a carrier (PLN/km) & 3.10 & 3.70 & 3.10 & 3.70 \\
Change of a carrier's rate (\%) & -11.4 & 5.7 & -11.4 & 5.7 \\
Increase of a carrier's profits (\%) & 33.5 & 102.1 & 33.5 & 102.1 \\
\hline \multirow{2}{*}{ Buildings materials } & Reduction of logistics costs of a transport user & & \\
\hline \multirow{2}{*}{ Garments } & value (PLN/vehicle) & & 13,000 \\
\cline { 2 - 5 } & $-1.7 \%$ & $-36.0 \%$ & $-1.6 \%$ \\
\hline
\end{tabular}

Source: Source: own on the base of data collected from the Polish transportation market in 2017 year. 
In all variants a carrier obtains considerable benefits - the biggest ones in variant "Better service". As for the benefits of a transport user the results can be a surprise but on the other hand are possible to explain.

In the variant "Better productivity" the logistics costs reduction is relatively bigger in case of cheaper building materials $(-1.7 \%)$, than in case of more expensive garments $(-0.3 \%)$, what can be a proof, that economizing on transport costs can bring small benefits.

Much more profitable is increasing the quality of service, but the benefits depend on the value of commodities bigger savings of logistics costs have been obtained in case of garments $(-82.3 \%)$ than building materials (-36.0\%).

This impact was lower for bigger fluctuations of demand $(-71.6 \%$, and $-33.2 \%$ respectively), what was the unexpected results. The explanation can be probably that providing good service when demand is unstable and unpredictable is costly.

\section{Conclusions}

The conducted simulations confirmed that there are benefits of outsourcing of transport and freight forwarding services and using service of high quality especially in case of goods of high value. The greatest impact have the quality of a service. The results of simulations seem to confirm the results of the research conducted for years, that the impact of the efficiency of logistics processes in the form of good logistic service of customers, may be more important than a reduction of costs (Tracey, 1998; Stank, Goldsby, Vickery, Savitskie, 2003; Qrunfleh, Tarafdar, 2013). Economizing on prices for transportation services, what is a common practice in this market (not only in Poland) is hard to justify. Reducing this price can have little impact on profitability of a transport user but even a small decrease of price can dramatically reduce profitability of transport carriers and freight forwarders. It seems, that not all companies are aware of this and understand the value of good quality of a service.

It should also be remembered, that not all benefits of outsourcing can be measured and not all of them can be expressed in the economical terms. The model presented in the paper can only be a support in making decisions concerning cooperation with external service providers. Final decisions should be made by managers in companies using transport and freight forwarding services.

\section{References}

Bergantino, A., Bierlaire, M., Catalano, M., Migliore, M., Amoroso, S. (2013). Taste heterogeneity and latent preferences in the choice behavior of freight transport operators. Transport Policy, 11 (30), 77-91.

Danielis, R., Marcucci, E., Rotaris, L. (2005). Logistics managers stated preferences for freight service attributes. Transportation Research, 3 (Part E 41), 201-215.

Hsiao, H.I., Kemp, R.G.M., van der Vorst, J., Omta, S.W.F. (2011) Logistics outsourcing by Taiwanese and Dutch food processing industries, British Food Journal, 113 (4), 550-576.

Kaczmarek, M. (2013). Rynek usług TSL w Polsce. rETRIEVED FROM: http://www.outsourcingportal.pl/pl/outsourcing/artykuly/rynekuslug-tsl-w-polsce.html.

Murphy, P.R., Daley, J.M. (1995). International freight freight forwarders: current activities and operational issues. International Journal of Purchasing \& Materials Management, 31 (3), 22-27.

Ozsomer, A., Mitri, M., Cavusgil, S.T. (1993). Selecting International Freight Freight forwarders: An Expert Systems Applications. International Journal of Physical Distribution and Logistics Management, 23 (3), 11-21.

Tongzon, J.L. (2009). Port choice and freight freight forwarders. Transportation Research, Part E 45, 186-195.

Qrunfleh, S., Tarafdar, M. (2013). Lean and agile supply chain strategies and supply chain responsiveness: the role of strategic supplier partnership and postponement. Supply Chain Management: An International Journal, 18 (6), 571-582. 
Tracey, M. (1998). The importance of logistics efficiency to customer service and firm performance. International Journal of Logistics Management, 9 (2). ABI/INFORM Complete, 65.

Stank, T.P., Goldsby, T.J., Vickery, S.K., Savitskie, K. (2003). Logistics service performance: estimating its influence on market share. Journal of Business Logistics, 24 (1), 27-55.

Wysocka, A. (2013). Determinants of industrial enterprises' decisions in relation to maintaining own-account transport in the light of research. Zeszyty Naukowe Uniwersytetu Szczecińskiego, 754. Problemy Transportu i Logistyki, 21, 255-263.

Załoga, Z., Milewski, D. (2004). Spedycja. Usługi i procesy. Szczecin: Wydawnictwo Naukowe Uniwersytetu Szczecińskiego.

Cite this article aS: Milewski, D. (2018). The economic efficiency of outsourcing of transport and logistics services. Case study of the Polish road transport market. European Journal of Service Management, 3 (27/1), 157-164. DOI: 10.18276/ejsm.2018.27/1-19. 